\title{
Algumas Reflexões sobre W. G. Sebald à Luz de Walter Benjamin
}

\section{Gerciano Maciel Pereira (UFMG)}

Resumo: O texto se constitui de três partes irmanadas pelas presenças de W. G. Sebald e Walter Benjamin. Sendo que a primeira discorre, amparada na concepção da "onipresença do choque/trauma" de Benjamin, sobre a temática da memória e da narrativa fraturada. A segunda disserta sobre o processo de espacialização do tempo, a partir da concepção benjaminiana de História e da escrita sebaldiana. Já a terceira, investiga a questão do deslocamento traumático, da viagem e do exílio, embasada no conceito/alegoria do flâneur e do detetive. Cada parte apresenta um conceito-imagem de Walter Benjamin, combinado a excertos do romance Os emigrantes de W. G. Sebald.

Palavras-chave: Incomunicabilidade; História; Memória

O narrador dos romances de Sebald é um tradutor da incomunicabilidade, pois enfrenta o apagamento coletivo da memória para desenterrar figuras desenraizadas pelo exílio e simbolicamente soterradas pela "tempestade" que "impele irresistivelmente para o futuro". Ao contrário do anjo da tese IX, de Walter Benjamin, Sebald consegue se desvencilhar do sopro que vem do paraíso, e voltar para juntar os cacos da história, e tirar dos escombros os mortos, que com suas histórias e memórias revelam o lado obscuro da evolução racionalista da humanidade. De fato, os personagens de W. G. Sebald carregam experiências inexprimíveis, devido a sua carga negativa. São portadores de uma incomunicabilidade correlata de um tempo em que a exceção é a regra e que o choque e o trauma se incorporaram ao cotidiano: em que o mal, tal como Arendt (2008) defende, se banalizou.

Incomunicabilidade, experiências intransmissíveis, memórias traumáticas, são conceitos ligados ao fim da narrativa tradicional. Reflexão presente nos ensaios "Experiência e Pobreza", e "O narrador", de Walter Benjamin. Nestes dois textos temos reflexões pontuais sobre o conceito de experiência coletiva, e uma constatação categórica a respeito do fim de sua comunicabilidade. Sendo que em ambos se repetem literalmente uma mesma passagem, síntese, para compreendermos o fím da experiência comunicável:

No final da guerra, observou-se que os combatentes voltavam mudos do campo de batalha não mais ricos, e sim mais pobres em experiência comunicável. E o que se difundiu dez anos depois, na enxurrada de livros sobre a guerra, nada tinha em comum com uma experiência transmitida de boca em boca. Não havia nada de anormal nisso. Porque nunca houve experiências mais radicalmente desmoralizadas que a experiência estratégica pela guerra de trincheiras, a experiência econômica pela inflação, a experiência do corpo pela guerra de material e a experiência ética pelos governantes. Uma geração que ainda fora à escola num bonde puxado a cavalos se encontrou ao ar livre numa paisagem em 
que nada permanecera inalterado, exceto as nuvens, e debaixo delas, num campo de forças de torrentes e explosões, o frágil e minúsculo corpo humano. ${ }^{1}$

Nesta passagem, observamos que a técnica irrompe agressivamente na paisagem artesanal, causando um corte por demais violento. Aqui, ocorre a experiência "ambivalente do estranhamento" resultante da combinação da paisagem familiar em "que nada permanecera inalterado", com "forças bélicas" tão inimagináveis que se assemelham às forças indomáveis da natureza primitiva. Trata-se da dupla conotação, segundo Freud (1974), da palavra "estranho" (Unheimlich) que remete tanto ao familiar quanto ao desconhecido. O estranho é familiar devido à recorrência, que perpassa o campo da coincidência cotidiana. Algo que reconhecemos e que já vivemos, mas permanecia oculto, e não deveria vir à tona. É este "retorno" de algo reprimido no subsolo do ego que provoca a sensação de desconforto. A força bélica despertou um medo recalcado no inconsciente da civilização: o medo dos primeiros homens ante a natureza esmagadora. Com o tempo, o homem dominou simbólica e tecnicamente a natureza, se pondo no centro do mundo. Mas justamente no auge do domínio do indivíduo sobre a natureza, por meio da ciência, este se vê novamente à mercê de forças incontroláveis. Além disso, temos o corte do cordão "transcendental" que conservava o indivíduo no protegido útero do "mundo explicado", ora pelo mito ora pela razão, impossibilitando a assimilação da experiência traumática, e conseqüentemente, tornandoa indizível.

Mas a condição de indizível, conforme defende Giorgio Agamben (2008), que cerca a experiência traumática não deve ser pretexto para resignação, pois, eleger o desumano como elemento inenarrável é dar a este um caráter místico. O que poderia criar uma atmosfera de culto em torno dos objetos de barbárie. Deste modo, em vez do silêncio, a complexidade do fato deve incentivar novas formas de narrar: a precariedade subjetiva criada pelo evento traumático deve ser incorporada à estrutura narrativa, ou nas palavras de Agamben:

Isso significa que o testemunho é o encontro entre duas impossibilidades de testemunhar, que a língua, para testemunhar, deve ceder lugar a uma nãolíngua, mostrar a impossibilidade de testemunhar. A língua do testemunho é uma língua que não significa mais, mas que, nesse seu ato de não-significar, avança no sem-língua até recolher outra insignificância, a da testemunha integral, de quem, por definição, não pode testemunhar, não basta levar a língua até ao próprio não-sentido, até à pura indecibilidade das letras (...); importa que o som sem sentido seja, por sua vez, voz de algo ou alguém que, por razões bem distintas, não pode testemunhar, a "lacuna" que constitui a língua humana, desaba sobre si mesma para dar lugar a uma outra impossibilidade de testemunhar - a daquilo que não tem língua. ${ }^{2}$

Narrar, contar, testemunhar aquilo que se encontra na "não-língua", pressupõe uma narrativa, um relato, que assuma seu fracasso, que se denuncie parcial, incompleto. Tratase de reconfigurar nossa percepção mimética. De fato, foram catástrofes do nível do holocausto que colocaram o nosso sistema representacional em crise. E, por conseguinte, exigiu uma nova concepção de narrativa e de história. Concepção que não ambiciona mais a completude e a totalidade, que não nivela as diferenças e os impasses da 
irracionalidade na tábua rasa da causalidade, ou na homogeneização temporal que tudo absorve na indiferença. Algo que Walter Benjamin já criticava com bastante veemência, pois esse continuum da sequencialidade histórica e da narrativa encobria os mortos com seus destroços e prosseguia, num fluxo ininterrupto. Com isso, temos a necessidade da “cesura', a interrupção da história. Além disso, a linguagem baseada no signo transparente é correlata dessa concepção narrativa e histórica, baseada na causalidade cronológica. Por isso mesmo, Benjamin preferiu reabilitar o conceito de alegoria, que ao representar se mostra opaca, obscura, inserindo ruídos na representação tradicional, dando "uma sintaxe ao grito", no dizer de Deleuze e Guatarri, se referindo a Kafka. Este último fundador de uma nova linhagem de narrativas, que trazem a lacuna deixada pelo abandono da convenção tradicional, que internalizam seu próprio fracasso, mostrando-se insuficientes ante uma realidade de extremos, em que tudo escapa. Ora, e não é exatamente este fracasso que vemos confessado ao fim de cada narrativa de W. G. Sebald? Sim, algo admitido diretamente no enunciado narrativo:

Durante os meses de inverno de 1990/1991, no pouco tempo de que dispunha, portanto em geral nos chamados fins de semana e à noite, trabalhei na história aqui relatada de Max Aurach. Era um trabalho muito laborioso, que muitas vezes empacava no mesmo ponto durante horas ou dias, e não raro voltando atrás, quando eu era constantemente atormentado por escrúpulos cada vez mais perceptíveis, que me paralisavam cada vez mais. Esses escrúpulos provavelmente tinham a ver com o objeto de minha narrativa, a que eu pensava não conseguir fazer justiça, e com a precariedade da profissão do escritor. Eu cobria centenas de páginas com rabiscos a lápis ou esferográfica. A maior parte disso tudo fora riscado, posto fora ou recoberto de acréscimo que quase o tornava ilegível. Mesmo aquilo que finalmente salvei como "definitiva" me pareceu um fracasso. ${ }^{3}$

A quebra metalinguísitica de autorreferir a narrativa apresentada como um fracasso decorre, como ele mesmo admite, de seus escrúpulos. O compromisso ético e a intenção estética às vezes não se coadunam. E o escritor "escrupuloso" tem que, de alguma forma, confessar seu fracasso. Uma das formas encontradas pelos escritores é incluir a lacuna em seu foco narrativo, limitar-se conscientemente a fim de se assemelhar verossimilmente com o ponto de vista de uma testemunha. E, conforme já vimos com Agamben, uma testemunha na maioria das vezes testemunha sobre a impossibilidade de testemunhar. Assim o enunciado narrativo aponta para fora de si mesmo, incorporando a cena de enunciação que o antecedeu. Isso suspende a ilusão de fechamento do texto, revelando sua incapacidade de representar, e abrindo linhas de fuga para fora da representação tradicional. Neste caso, um escrúpulo ético desencadeia uma maior exigência estética, a forma então corporifica o impasse ético do narrador-testemunha. $\mathrm{Ou}$ seja, o fracasso do narrador ao tentar apreender seu objeto é metonímico de um fracasso ainda maior: da razão instrumental, do realismo tradicional, de uma concepção de História equivocada, da representação em geral. Esse processo de inserir a lacuna, o opaco, na narrativa, desmonta ambições miméticas totalizadoras, e a partir das raspas e ruínas, dos refugos das catástrofes que cimentam a História, adiantam na expressão o que se encontra recalcado sob um consciente coletivo padronizado. Com isso, o narrador

Cadernos Benjaminianos, n. 3, Belo Horizonte, jan.-jun. 2011, p.71-86 
sebaldiano incorpora a subjetividade problemática à forma, intensificando esteticamente a condição traumática.

\section{O Colecionador ou o Tempo Sólido}

O tempo nos alerta sobre sua passagem ininterrupta no momento em que toca agressivamente a face da matéria. Enquanto um objeto resiste ao arranhar diário, sem se desfigurar, o toleramos. Às vezes, por uma questão afetiva, maquiamos os primeiros hematomas, a fim de protelar a separação. Mas quando estas marcas se evidenciam de maneira irrevogável, então, a presença desse objeto desfigurado torna-se insuportável. Uma vez que sua presença passa a ser a indicação sólida e incontornável da mortalidade. É nesta ocasião que as coisas são rebatizadas. E os objetos passam a ser chamados de sucatas, de ruínas. E são removidos, substituídos.

A partir de então os objetos desfigurados pelo tempo passarão a interessar apenas aos excêntricos, aos colecionadores ou aos sucateiros. Personalidades que admiram as coisas pela sua utilidade secundária, ou mesmo, pela sua falta de utilidade. Baseada nessa premissa, Walter Benjamin desenvolve os conceitos-alegóricos do Colecionador e do Chiffonier, isto é, do sucateiro ou trapeiro. Este último Walter Benjamin retira da poesia de Baudelaire. Quanto à figura do colecionador, enquanto imagem-conceito origina-se da própria personalidade de Benjamin, um inveterado colecionador de livro, um tanto extravagante. Tanto que nas condições financeiras mais adversas manteve o hábito de frequentar leilões de livros raros, e adquiri-los. Expandindo até o último momento, sua lendária biblioteca.

A atitude do colecionador para Benjamin conserva algo de anárquico, ao mesmo tempo em que sustenta uma postura de preservação. Uma coleção inevitavelmente aponta para uma idéia de ordem e sistematização. Mas esta ordem que guia o espírito colecionador é ilusória. Colecionar no conceito de Benjamin é antes uma atitude destrutiva. Pois quando o colecionador se interessa por algo, imediatamente encerra o objeto preterido no campo restrito da posse. Isto o retira do âmbito comum, ou melhor, o que em um determinado contexto histórico compareceu como algo inteiramente inserido na rotina ordinária da utilidade, pode se tornar sob olhar excêntrico do colecionador, algo exclusivo. $\mathrm{O}$ interesse do colecionador cresce no momento em que a tradição morre. A tradição mantém os objetos dentro de hierarquia valorativa e classificatória. Fora da tradição as coisas são limpas de classificação e também de sua utilidade. E ficam a serviço do colecionador.

A figura do colecionador torna-se importante para a concepção de história de Walter Benjamin, porque este acreditava no valor testemunhal das coisas. Para ele os objetos mais insignificantes podem acumular o que existiu de singular de uma época. Pois, o que nos parece mais inútil hoje é porque sem dúvida foi fruto de uma forma de viver já extinta, por isso mesmo ele só poderia pertencer à época que gerou demanda para sua existência. O motivo de Benjamin acreditar neste poder das coisas de reter significados históricos singulares deve-se a maneira como reinterpretou o conceito de infraestrutura e superestrutura de Marx. Tal como destaca Hanna Arendt em seu texto sobre Walter Benjamin: "o aspecto teórica que acabaria por fasciná-lo era doutrina da superestrutura", porém "o que aí o fascinava era que o espírito e sua manifestação material estavam tão intimamente ligados que parecia possível descobrir, em todas as partes, as correspondances de Baudelaire" e "se fossem adequadamente correlacionadas, se 
esclareceriam e se iluminariam uma às outras de modo que, ao final, não mais precisariam de nenhum comentário interpretativo ou explicativo" ${ }^{4}$. Essa forma direta se associa ao acontecimento no campo "do espírito" a um fator material, sem intermediários interpretativos, que provocou a acusação por parte de Adorno a Walter Benjamin de não ser suficientemente dialético em seu artigo sobre Baudelaire. Mas não ser dialético era exatamente o que Benjamin pretendia: "tentativa de capturar o retrato da história nas representações mais insignificantes da realidade, por assim dizer em suas raspas" 5. Benjamin acreditava que a recolagem das "raspas", dos cacos da História, sem mediações explicativas, ou causais, tem a ver com a intervenção alegórica de liberar os objetos históricos do continuum da história a que tradição os relegou, ou mesmo de ressignificálos.

Os objetos são para o colecionador-narrador escombros de uma catástrofe. Esta catástrofe é o progresso. O narrador-colecionador é uma figura saturnina e obsessiva. E tem um senso infantil que ignora e desrespeita a lógico e a razão que patrocinam o progresso, que na sua visão é apenas um produtor de ruínas. Suas atitudes são irracionais e românticas. Mas o romântico é apenas alguém insatisfeito com o seu próprio tempo. É a vítima por excelência da modernidade. E o narrador sebaldiano exemplifica perfeitamente a imagem deste colecionador de ruínas. Sentimentalmente deslocado de seu tempo. E que ler as ruínas inversamente aos entusiastas. Pois para ele elas são vestígios de uma pátria perdida, de seu antigo lar. Há nele uma afetação nostálgica. Mas a nostalgia no caso de Sebald e Benjamin não pode ser interpretada no sentido reacionário ou fascista. Pois não existe nenhuma razão pela qual a nostalgia "consciente de si mesma, uma insatisfação com o presente, lúcida e sem remorsos, fundamentada em alguma plenitude relembrada, não possa fornecer um estímulo revolucionário" " ${ }^{\circ}$. É essa insatisfação análoga a melancolia mórbida, patológica, que impede o indivíduo de voltar ao convívio feliz e celebrativo. O luto por ultrapassar a barreira do salutar lhe possibilita ver, tal como o príncipe Hamlet, que quem está no poder tem as mãos sujas de sangue e, à noite, os fantasmas cercam o reino clamando vingança. Este olhar enlutado cria uma postura interrogativa e desconfiada, pessimista. Tal como a concepção barroca de tempo e história interpretada por Benjamin:

Quando, com o drama barroco [ trauerspiel ], a história adentra no palco, ela o faz como escrita. Na face da natureza encontra-se a palavra "história", com os caracteres da transitoriedade. A fisionomia alegórica da natureza-história, que é posta na cena com o Trauerspiel, é efetivamente presente enquanto ruína. [...] O que encontra-se aí desfeito em escombros, o fragmento altamente significativo: esta é matéria da criação barroca. ${ }^{7}$

Neste ponto poderíamos dizer que W. G. Sebald compartilha desta mesma concepção barroca de tempo e história. O homem barroco vê a história como uma grande pilha de cadáveres, pois este já não nutre nenhuma fé transcendental, com isso ele se agarra na imanência, na superfície material das coisas, nas ruínas, que é a verdadeira manifestação da história, pois mensura a transitoriedade na gradação física de seu corpo. O narrador sebaldiano também não compartilha da visão transcendental da história. Por isso não celebra o progresso e a modernização impressionante que se seguiu no pós-guerra, pois nada disso trará os mortos novamente. Com isso, Sebald olha o tempo presente e vê nele sempre a marca da destruição:

Cadernos Benjaminianos, n. 3, Belo Horizonte, jan.-jun. 2011, p.71-86 
Não sei se insensatamente eu esperava algo especial de Deauville - um resto de passado, alamedas verdes, passeios na praia ou um público mundano ou semimundano; não importa quais eram minhas fantasias, logo vi que essa praia de mar outrora lendária estava implacavelmente decadente, como qualquer outro lugar que se visite hoje, não importa em que parte do mundo ou em que país, arruinada pelo tráfego de carros, pelo comércio de butiques e pelo ímpeto destrutivo que cada vez se espalha mais. ${ }^{8}$

Como vemos o narrador se desaponta com a praia de Deauville, por ver nela sinais de decadência. Mas na progressão de sua descrição percebemos que as marcas de decadência na verdade é o que em uma visão capitalista e consumista chamaria de modernização, pois supostamente o local estaria com infraestrutura mais variada de comércio e estaria mais frequentado. Porém, é exatamente essa modernização, interpretada como "ímpeto destrutivo", que o desagrada. E ao estender este diagnóstico de decadência para todo o resto, o narrador deixa claro que o problema não está em Deuville, mas sim em sua visão de mundo que destoa da concepção geral vigente.

Deste modo, Sebald lê a paisagem criada pela ideologia vigente como ruína. Ele entende que a cultura, o modo de vida, assim como os seus bens culturais também fazem parte do espólio de guerra dos vencedores:

Os despojos são carregados no cortejo, como de praxe. Esses despojos são o que chamamos bens culturais. $O$ materialista os contempla com distanciamento. Pois todos os bens culturais que ele vê têm uma origem sobre a qual ele não pode refletir sem horror. Deve sua existência não somente ao esforço dos grandes gênios que os criaram, como à corvéia anônima dos seus contemporâneos. Nunca houve um monumento da cultura que não fosse também um monumento da barbárie. E, assim como a cultura não é isenta de barbárie não o é, tampouco, o processo de transmissão da cultura. Por isso, na medida do possível o materialista histórico se desvia dela. Considera sua tarefa escovar a história a contrapelo. ${ }^{9}$

Ler a história a contrapelo significa ir contra a corrente do desenvolvimento naturalizado como se seguisse uma ordem divinal e incontestável, isso pressupõe a rejeição dos bens culturais e das ideologias de vidas impostas pelas ideologias vencedoras. Como diz Löwy (2005) comentando o trecho transcrito acima, a revolução não acontecerá graças ao curso "natural das coisas", pois, "deixada à própria sorte, ou acariciada no sentido do pêlo, a história somente produzirá novas guerras, novas catástrofes, novas formas de barbárie e de opressão." ${ }^{10} \cdot$. Neste sentido o fluxo constante da história deve ser interrompido. Pois, a maneira como os fatos são interligados passam a impressão que um acontecimento se liga a outro por um processo automático e mecanicista. Encaminhando-se para uma totalidade, tal concepção se embasa em uma noção linear e homogênea de tempo, na qual o passado espera passivamente ser resgatado palmo a palmo. Quando na verdade este passado só existe enquanto resíduos retidos no presente.

Assim, os acontecimentos não possuem nada que os liguem intrinsecamente. Um fato histórico importante talvez seja inexpressivo para sua época, ou sua validação seja feita

Cadernos Benjaminianos, n. 3, Belo Horizonte, jan.-jun. 2011, p.71-86 
depois. Os heróis podem ser apenas desorientados, vítimas do acaso, que a posteridade retoma não pelas suas qualidades, mas para projetar nele seus anseios e ideais. Por isso Walter Benjamin defender que o tempo da escrita, o presente, ser o mais importante, pois "articular historicamente o passado não significa conhecê-lo 'como ele de fato foi'. Significa apropria-se de uma reminiscência, tal como ela lampeja no momento de um perigo." ${ }^{11}$ Desta forma, os objetos devem ser retirados do molde da linearidade, a qual a tradição e a ideologia dominante os subornou, e mais uma vez a figura do narradorcolecionador mostra-se essencial. Pois, "a história repousa numa prática de coleta de informações, de separação e de exposição dos elementos, prática muito mais aparentada àquela do colecionador, figura-chave da filosofia e, também da vida de Benjamin" do que "àquela do historiador no sentido moderno que tenta estabelecer uma relação causal entre os acontecimentos do passado." 12 Com isso, Benjamin defende o salto para fora da história, ou melhor, para fora do discurso nivelador e conformado da tradição.

Os objetos da história nas mãos do historiador "benjaminiano", ou de qualquer um que pretenda narrar, sob esta perspectiva, tornam-se "brutos". Ou melhor, o narrador "alegorista-colecionador" cata seus objetos da história, no momento em que estes se tornam inúteis, quando são abandonados pela ideologia que os gerou, passam a valer pelo seu sentido "material", perdem seu significado para se tornarem significantes. Ou como esclarece Benjamin:

Sob a aparência ensimesmada da melancolia, o objeto, uma vez que se torna alegórico, uma vez que a vida correu para fora dele, fica para trás, morto, e no entanto preservado para toda a eternidade; jaz diante do alegorista, completamente entrega a ele, para bem ou para o mal. Em outras palavras, o objeto é doravante incapaz de projetar qualquer significado por conta própria; pode tão-somente assumir aquele significado que o alegorista lhe conferir. Ele o instila com seu próprio significado, ele próprio desce para habitá-lo: e isso deve ser compreendido não psicologicamente, mas num sentido ontológico. Em suas mãos, o objeto em questão torna-se uma outra coisa, fala de outra coisa, passa a ser para ele a chave para alguns domínio de conhecimento abscôndito, ao qual, enquanto emblema deste último, ele presta homenagem. Isto é o que constitui a natureza da alegoria enquanto escrita. ${ }^{13}$

Neste aspecto, talvez não exista na contemporaneidade escritor de escrita mais alegórica do que W. G. Sebald. Alegórica no sentido esboçado acima, isto é, de se apropriar, pelo viés da melancolia, dos objetos, no momento em que estes perdem quase seu significado para os outros. Tanto que uma das imagens mais recorrente na obra de Sebald são aquelas em que o narrador se posiciona diante de prédios monumentais, que outrora foram importantes, mas que agora jazem em ruínas, interessando apenas aos melancólicos. Antes de descrevê-los minuciosamente, Sebald sempre faz questão de contar a trajetória destes, de contextualizá-los em seu esplendor de ocaso, exaurindo destas passagens uma prosa de matizes decadentistas:

Segundo ainda consegui descobrir, nos anos cinquenta ou sessenta o Roches Noires cessara suas atividades e fora dividido em apartamentos dos quais só os que tinham vista para o mar foram vendidos. Hoje esse que foi um dia o mais luxuoso hotel da costa normanda é uma monstruosidade monumental,

Cadernos Benjaminianos, n. 3, Belo Horizonte, jan.-jun. 2011, p.71-86 
metade já soterrada na areia. A maior parte das moradias está abandonada há muito, mortos os seus donos. Mas algumas damas indestrutíveis ainda continuam vindo todos os verões e são como fantasmas na gigantesca edificação. Por algumas semanas tiram dos móveis os panejamentos brancos que os cobrem, à noite deitam-se quietas como sobre catafalcos em algum lugar no meio daquele vazio, perambulam pelos amplos corredores, atravessam salões imensos, sobem e descem pelas escadarias cheias de ecos botando um pé cuidadosamente diante do outro, e cedo pela manhã levam a passear na calçada seus pequineses e poodles cobertos de feridas. ${ }^{14}$

Sebald parece se interessar pelas coisas no momento em que estas se tornam decadentes. É como se seu espírito melancólico buscasse morada numa paisagem que por precariedade, valida e corporifica sua melancolia. Mas não se trata só disso. As narrativas de Sebald se passam em parte num contexto histórico remoto, tendo em vista o tempo da escritura, mas mesmo assim não vemos nenhuma tentativa de reconstituição deste passado, o narrador só tem deste passado o que sua erudição permite ter. Mas a certa altura um estranho sopro de nostalgia é ruflada das páginas. E isto acontece porque Sebald, seguindo a técnica alegórica, escolhe um "fragmento altamente significativo" para alcançar um ponto obscuro de determinada época. Sebald se apropria dos objetos esvaziados e desabitados de sentido para homenagear ou evocar uma face esconsa da História. Ou como diria Benjamin, Sebald realiza uma releitura da história, por meio de uma exposição mosaica de ruínas e de fragmentos.

Sebald realiza uma re-investida de sentido, uma tradução/ressifignicação da linguagem das ruínas. O tempo nesta escrita adquire uma dimensão espacial, ele se materializa em imagens alegóricas, o tempo é adensado em sua instância maior: o espaço. A memória em Sebald é, tal como sugere Seligmann-Silva, topográfica. Isto porque a memória nunca se desenrola no vácuo. Mas se molda, como os dedos sobre o veludo, na superfície material dos objetos que compõe o espaço afetivo, objetos humanizados, plenamente mergulhado em nossa subjetividade.

O historiador/colecionador tem que ser seletivo e oportunista, não basta colher o escombros e fragmentos indiferentemente. Como diz Benjamin "a verdadeira imagem do passado perpassa, veloz. O passado só se deixa fixar, como imagem que relampeja irreversivelmente, no momento em que é reconhecido." ${ }^{15}$ Deste modo, o narrador/alegorista deve se manter em constante vigília para as manifestações do passado, para as coincidências ou para os lapsos de imagens lampejados pela memória involuntária:

O historiador deve ter presença de espírito (geistesgegenwart) para apanhar essas imagens nos momentos que elas se oferecem: assim ele pode salvá-las, paralisando-as. Essa história construída com base na memória involuntária despreza e liquida o "momento épico da exposição da história", ou seja, a sua representação segundo uma narração ordenada monologicamente. "A memória involuntária nunca oferece [...] um percurso mas sim uma imagem." 16

W. G. Sebald estrutura quase todas as suas narrativas em cima de imagens involuntárias, sobre uma coincidência em que o passado retorna com os seus mortos e o 
interpela a escrever sobre ele. Uma destas coincidências, ou imagem involuntária da memória é a que aparece na primeira narrativa de Os emigrantes, intitulada "O Dr. Henry Selwyn". Nesta Sebald nos conta sobre o personagem que nomeia a narrativa. Uma figura recolhida e triste, que com resistência conta a Sebald sobre seu sofrido passado de exilado judeu. Em meio às pesadas recordações, apenas uma lhe parece despertar felicidade: a de sua amizade com um guia de montanha, Johannes Naegeli, com experiência de seus 65 anos. Henry Selwyn então com seus vinte um anos, recémformado em Medicina. Mas veio a guerra. Eles se separaram. Sebald depois de ouvir a história do Dr. Henry também deixa a cidade e o casarão que a triste figura habitava. Até que um dia

\begin{abstract}
Algumas semanas depois no fim do verão, ele se matou de sua pesada espingarda de caça. Como ficamos sabendo em nosso regresso, ele se sentara na beira da cama, botara a arma entre as pernas, pousara o queixo na ponta do cano em seguida pela primeira vez desde que comprara a arma antes de viajar para a índia, disparara um tiro com intenção de matar. Quando recebemos a noticia não me foi difícil vencer o horror inicial, mas cada vez entendo melhor, certas coisas têm um jeito inesperado de retornar, muitas vezes depois de longo tempo ausentes. Pelo fim de julho 1986 passei alguns dias na suíça. Na manhã do dia 23 fui de trem de Zurique a Lausanne. Quando o trem cruzou lentamente a ponte do Aare, entrando em Berna meu olhar viajou da cidade à cadeia de montanhas. Se não estou apenas imaginando agora, lembrei-me dr. Selwyn nessa ocasião pela primeira vez depois de muito tempo. Quarenta e cinco minutos depois, para não perder a visão daquela magnífica paisagem do lago de Genebra, já deixando de lado um jornal de Lausanne comprado em Zurique, que estivera folheando, quando uma noticia chamou minha atenção: dizia que os restos mortais de Guia de montanhas Johannes Naegeli, desaparecido desde o verão de 1914, tinha sido devolvido depois de 72 anos pela geleira de Oberaar. - Assim, pois, retornam os mortos. Às vezes depois demais de sete décadas eles saem do gelo e ficam na beira da morena, um montinho de ossos polidos e pá de botas com cravos. ${ }^{17}$
\end{abstract}

Essa passagem encerra a narrativa, assim só no final ficamos sabendo que o narrador ao contar a história do Dr. Henry Selwyn estava atendendo a um chamado de uma imagem involuntária da memória combinada com a coincidência da notícia de jornal. A imagem do corpo que a geleira cristalizou durante 72 anos, para devolvê-los limpos, serve-nos perfeitamente como imagem-alegórica para ilustrarmos a questão de que, em determinado ocasião, os objetos saltam do discurso cristalizado da História, para tornarem a ser limpos, brutos, para ficar à disposição de nossa apropriação. Mas esta passagem serve para esclarecer como Sebald se mostra um narrador atento e suficiente capaz de captar a fugaz imagem do passado, para fazer dela um fragmento privilegiado que lhe permitirá reler a História. Há nesta imagem a manifestação ideal do Kairos, isto é, uma ocasião de coincidência que nos interpela frontalmente uma reflexão, ou nas palavras de Proust, que cito via Gagnebin: "é um acaso mais raro, um acaso selecionado e submetido a condições difíceis, depois de provas eliminatórias, que levam de volta ao espírito um objeto outrora perdido" ${ }^{18}$. Este extremo acaso, que impõe uma ascese, deve

Cadernos Benjaminianos, n. 3, Belo Horizonte, jan.-jun. 2011, p.71-86 
ser acompanhado de uma investigação, pois este traz sempre uma verdade inusitada do passado.

\section{O Detetive e o Flaneur}

O deslocamento na obra de W. G. Sebald é uma constante que repercute em todas as etapas da conjuntura de seus romances. Para começar, a sua temática envolve uma busca, uma investigação, que pressupõe um movimento de recolha, tanto de fragmentos físicos, quanto subjetivos. Dentre os físicos incluímos fotografias, documentos, diários, cartões postais, cartas, dentre outros. Esses impulsionam o deslocar pragmático do investigadorviajante que tenta arrolar provas concretas que delimitem substancialmente a imagem, muitas vezes fantasmal, de seus personagens. Disso, vemos o narrador sebaldiano empenhando viagens em prol de um documento, uma fotografia, uma lápide, algo que marque a passagem de pessoas que morreram em trânsito, em fuga. Já entre os motivos subjetivos, temos um lapso de memória, um surto afetivo, uma coincidência que provoca estranheza, ou mesmo o simples vazio existencial que desperta no narrador a vontade da errância, do peregrinar introspectivo e meditativo, que funciona como catarse, mas não só, uma vez que atende uma empatia com o perdido, que apesar de ser romântica é, antes, compromissada eticamente com os mortos e injustiçados.

Além disso, a temática do deslocamento marca materialmente o texto de W. G. Sebald, seja pela sintaxe que não descansa, com suas frases longas e parágrafos em bloco enormes, que parecem querer sempre ir além, ou pela confluência de línguas, como italiano, inglês, francês que invadem o texto, babeliza-o, apontando a condição de eterno estrangeiro do narrador. Sua insatisfação o leva a deambular solitariamente. Um caminhante que vaga por entre ruínas e cemitérios. É um flâneur, mas, se o flâneur se movimenta de acordo com seu lirismo e ociosidade, o flâneur sebaldiano combina o lirismo melancólico com uma postura investigativa. Ele funde o flâneur com o detetive. Essa fusão já foi feita por Benjamin para descrever o indivíduo moderno. Os pressupostos que o embasam são as obras de Edgar Allan Poe e Charles Baudelaire. Estes dois poetas foram os primeiros a se preocupar com o impacto da modernidade sobre a identidade. Sob o crivo de Walter Benjamin estes se transformam em imagens conceituais:

Em tempos de terror, quando cada qual tem em si algo do conspirador, o papel do detetive pode também ser desempenhado. Para tal a flânerie oferece as melhores perspectivas. "O observador - diz Baudelaire - é um príncipe que por toda a parte, faz uso do seu incógnito". Desse modo, se o flâneur se torna sem querer detetive, socialmente a transformação lhe assenta muito bem, pois justifica a sua ociosidade. Sua indolência é apenas aparente. Nela se esconde a vigilância de um observador que não perde de vista seu malfeitor. Assim o detetive vê abrirem-se à sua auto-estima vastos domínios. Desenvolve formas de reagir convenientes ao ritmo da cidade grande. Capta as coisas em pleno voo, podendo assim imaginar-se próximo ao artista. ${ }^{19}$

Assim, o detetive-flâneur é um solitário em meio à multidão que tem a disciplina cientifica dos detetives de Poe, e a sensibilidade e a melancolia do "eu" lírico de Baudelaire. Com isso, inteligência e sensibilidade são combinadas para criar um 
personagem que vagueia pela cidade, submerso na multidão, seu andar inicia-se desorientado, mas sua disposição poética permite extrair da corporeidade da cidade a poesia, e o mesmo olhar aguçado de poeta favorece o cálculo investigativo. Sebald assim como o detetive-flâneur vê a cidade moderna como o local de um crime. Onde todos podem ser "conspiradores", vítimas e "testemunhas". E como ressalta Benjamin: "qualquer pista seguida pelo flâneur vai conduzi-lo a um crime" ${ }^{20}$. Com isso, as pistas para a resolução dos crimes da história estão nos vestígios mais desprezíveis. O olhar do flâneur não se guia pragmaticamente e se comove com o que já é considerado ruína para a maioria. Fugir do óbvio pode ser a chave para solucionar um crime. O detalhe que só a apurada lupa capta contém a pista que denuncia o "malfeitor". Sebald como detetiveflâneur ao encontrar uma vítima, mesmo que agonizante, não se inibe em interrogá-la. Antigos objetos, às vezes irrelevantes, entram no rol das provas. Mas as investigações de Sebald sempre fracassam. Pois a razão aqui não é aliada. Ela é a grande criminosa. Nisso se assemelha a Baudelaire. O poeta "maldito" era na verdade um comovido. Admirava a proposta de Edgar Allan Poe de aproximar arte e ciência, de disciplinar as expressões artísticas à luz das admoestações científicas, mas nunca a colocou em prática. O destino, a composição de uma vida segue veias de possibilidades infindas, e as coincidências mantém uma freqüência de inverossimilhança que intimida até mesmo a criação artística. Baudelaire preferia o desvio, a distração. Como diz Benjamin, o flâneur triunfa por mediar distração e observação. O olhar fixo e exato se transforma em estupefação. Distrair-se é permitir que a coisa observada também receba a marca de seus pensamentos. Baudelaire admirava a disciplina, e o trabalho em detrimento da inspiração, mas a poesia nasce justamente no momento em que o trabalho fracassa. A poesia é o gemido de dor e cansaço deste derrotado. O mesmo ocorre a Sebald, a inteligência e a erudição o direcionam em um primeiro momento, mas sua comoção e sua estranha identificação com os mortos o desviam aos porões da racionalidade ocidental. Seus escritos conservam a marca da derrota, porém, esta derrota é desejada: o mal e o terror produzido pelo lado B do Ser Humano não se subordinam as investidas racionais, o mesmo pode ser dito ao correspondente narrativo destas investidas.

W. G. Sebald não faz essas investidas racionais, ele não tem fé na instituição humana, ele é um narrador em luto permanente. Não é a toa que Os emigrantes se inicia com a imagem de um cemitério, como também se encerra, com o narrador emocionado ante as sepulturas dos judeus exterminados, e indignado com a displicência dos vivos em relação aos mortos:

Embora durante minha estada de vários dias em Kissingen e em Steinach, que já nada preserva de seu antigo caráter, eu me ocupasse bastante com minha pesquisa e adiantasse, como sempre laboriosamente, a minha escrita, senti cada vez mais que o empobrecimento espiritual que me rodeava, e a falta de memória dos alemães, a habilidade com que tudo fora removido e limpo, começava a atacar meus nervos e minha cabeça. ${ }^{21}$

A habilidade alemã de "limpar" e remover os detritos, de varrer para o subsolo da história, a vergonha e os seus mortos. Não é, diga-se, uma habilidade somente alemã. Mas sim, algo cada vez mais vitorioso nos dias de hoje. O luto e o apego aos mortos, ao perdido, aos vencidos são vistos como um ato de morbidez. Este desprezo por tudo que leve a marca da morte, Benjamin atribui a forma asséptica como a morte passou a ser 
tratada no mundo burguês: "durante o século XIX, a sociedade burguesa produziu, com as instituições higiênicas e sociais, privadas e públicas, um efeito colateral que inconscientemente talvez tivesse seu objetivo principal: permitir aos homens evitarem o espetáculo da morte" ${ }^{22}$. Os mortos são retirados do mundo dos vivos, sob argumentos de limpeza, medidas higiênicas. Passam a ser tidos como resíduos, ruínas, o que antes era fonte de culto e celebração.

Na Idade Média, o momento da morte era público, acompanhado atentamente por testemunhas ansiosas por colher as últimas palavras do convalescente, pois se consideravam que estas palavras estavam decantadas e destiladas em sua sabedoria. Com isso até mesmo "um pobre-diabo" tinha algo a ensinar aos vivos momentos antes de sua morte. Isto porque, naquele momento, "o saber e a sabedoria do homem e sobretudo sua existência vivida - e é dessa substancia que são feitas as historias - assumem pela primeira vez uma forma transmissível" ${ }^{23}$. Esta experiência secular, em contexto estável e artesanal, era um conhecimento imprescindível para a manutenção da vida, da continuidade. Mas, em tempos em que a existência humana se incorpora e se torna contingência da técnica e da tecnologia, sua trajetória se acelera, e a velocidade e a demanda do novo impulsionam ao devir. E qualquer movimento, do olhar, inclusive, que não esteja fixado no futuro, é encarado como retrocesso, saturnismo passadista. Mas Sebald consegue parar o tempo, saindo do cortejo frenético que marcha para o futuro, e como um típico flâneur, se detém absorto, para contemplar um prédio em ruína, uma lápide, um carvalho frondoso, para ouvir um moribundo. Desobedece a ordem de nunca "olhar para trás" e com o risco de se tornar "uma estátua de sal" fixa o olhar nos condenados à extinção.

Sebald se dedica a uma "causa perdida". Disso provém a melancolia e a dignidade que sua narrativa suscita. Há nisso uma dose daquele idealismo quixotesco sendo esmagado pelo mundo prático, ou mesmo o desconsolo dos personagens de Flaubert, que são apresentados com suas esperanças e sonhos no começo da narrativa, para serem em seu decorrer, dissecados e esvaziados de qualquer otimismo. Sobre este persistir em uma causa perdida, Edward Said dedica um pequeno ensaio, intitulado "Sobre causas perdidas". Valendo-se de escritos produzidos por escritores próximos da morte. Ele analisa este confronto de uma vontade individual que se choca contra a vontade coletiva, ou a coadunação das vontades que gera a sentença de que algo se encontra irreversivelmente perdido. Ou mesmo, da coragem, talvez suicida de não se resignar ante o fim inevitável, a derrota consumada. Baseado em Adorno ele destaca que, se um ideal é mantido com dignidade e com presteza intelectual, não importa se a regra geral decrete sua causa como perdida. É compromisso do intelectual e do escritor manter, nem que seja na esfera do pensamento ensimesmado, a coerência de suas idéias. Uma "causa" sempre é maior do que o indivíduo. Isso significa que nada impede na geração seguinte que aquilo que parecia fruto de uma obsessão idiossincrática, não seja retomado como o ideal coletivo. Levando a perguntar até quando uma causa pode ser considerada realmente perdida? Said prefere responder a isto como uma citação de Adorno:

[....] o pensador crítico intransigente, que não sobrescrita sua consciência nem se permite ser aterrorizado para entrar em ação, é, na verdade, alguém que não desiste. Alem disso, pensar não é reprodução espiritual daquilo que existe. Enquanto não é interrompido, o pensamento mantém um controle

Cadernos Benjaminianos, n. 3, Belo Horizonte, jan.-jun. 2011, p.71-86 
firme da possibilidade. Sua qualidade insaciável, a resistência a saciedade trivial, rejeita a sabedoria tola da resignação. ${ }^{24}$

É com essa intransigência que parece sublimar os modismos da vez, que o narrador presente em todos os romances de W. G. Sebald inventaria os destroços, entrevista os semivivos, que não sustentam a esperança no futuro e não podem se refugiar no passado, pois lá reside sua dor, e são ignorados pelo presente. Essas categorias de tempo nem sequer fazem sentido, para indivíduos desprovidos de desejo. A incomunicabilidade, que percebemos ao ler Sebald, não reside no silêncio, na incapacidade de contar. Mas no entrecruzar de duas temporalidades, ou melhor, no esforço de uma temporalidade em suplantar a outra, encontramos um intervalo, um limbo de indecisão, em que os seus habitantes narram, cantam, mas tudo que é dito não pode ser mais encoberto pela experiência, e se tornam gestos obscuros, resíduo intraduzível.

Abstract: This text has parts on W. G. Sebald e Walter Benjamin. Since the first talks, supported the concept of "ubiquity of shock / trauma " of Benjamin, on the theme of memory and narrative fractured. The second talks about the process of spatialization of time, from Benjamin's conception of history and writing sebaldiana. The third investigates the issue of traumatic displacement, travel and exile, based on the concept / allegory of the flâneur and the detective. Each party presents a concept image of Walter Benjamin, combined with excerpts from the novel by $O s$ emigrantes by W. G. Sebald

Keywords: Incommunicability, History, Memory

\section{Referências Bibliográficas}

AGAMBEN, Giorgio. Estado de Exceção. São Paulo: Boitempo, 2008

. O que resta de Auschwitz. São Paulo: Boitempo, 2008.

ARENDT, Hannah. Homens em tempos sombrios. São Paulo: Companhia de Bolso, 2008.

BHABHA, Homi. O local da cultura. Belo Horizonte: Ed. UFMG, 1998

BAKHTIN, Mikhail. Questões de Literatura e de Estética. São Paulo: Hucitec, 1998 . Marxismo e Filosofia da Linguagem. São Paulo: Hucitec, 1992.

BENJAMIN, Andrew; OSBORNE, Peter (orgs.) A filosofia de Walter Benjamin: destruição e experiência. Rio de Janeiro: Jorge Zahar Ed., 1997.

Cadernos Benjaminianos, n. 3, Belo Horizonte, jan.-jun. 2011, p.71-86 
BENJAMIN, Walter. Magia e técnica, arte e política. São Paulo: Brasiliense, 1994. . A origem do drama barroco alemão. São Paulo: Brasiliense, 1984. . Rua de mão única. São Paulo: Brasiliense, 1987.

. Charles Baudelaire: um lírico no auge do capitalismo. São Paulo: Brasiliense, 1989.

BLOCH, Ernst. O Encanto da Viagem, Antiguidades, Felicidade no Romance de Terror". In: O Princípio Esperança, vol. 1. Rio de Janeiro: Contraponto, 2005.

CARONE, Modesto. Lição de Kafka. São Paulo: Companhia das Letras, 2009.

DELEUZE, Gilles; GUATTARI, Félix. Kafka: por uma literatura menor. Rio de Janeiro: Imago, 1977.

FREUD, Sigmund. O Estranho. In: Edição Standard Brasileiras das Obras Completas de Sigmund Freud, v. XVII. Rio de Janeiro: Imago, 1974.

GAGNEBIN, Jeanne Marie. Historia e narração em Walter Benjamin. São Paulo: Perspectiva/FAPESP; Campinas: Editora da UNICAMP, 1994. . Lembrar escrever esquecer. São Paulo: Editora 34, 2006.

. Mímesis e crítica da representação em Walter Benjamin. In: DUARTE, Rodrigo, FIGUEIREDO, Virginia. Mimesis e expressão. Belo Horizonte: Ed. UFMG, 2001. Walter Benjamin - Os Cacos da História. São Paulo: Ed. Brasiliense, 1982

HALL, Stuart. Da diáspora: identidades e mediações culturais. Belo Horizonte: Editora UFMG, 2003.

HALBWACHS, Maurice. A Memória Coletiva. São Paulo: Ed. Vértice, 1990.

JAMESON, Fredric. Marxismo e forma: teorias dialéticas da literatura no século XX. São Paulo: Hucitec, 1985.

KRISTEVA, Julia. Estrangeiro para nós mesmos. Rio de Janeiro: Rocco, 1994.

LEJEUNE, Philippe. O pacto autobiográfico: de Rousseau à internet. Belo Horizonte: Ed. Da UFMG, 2008.

LÖWY, Michel. Walter Benjamin - aviso de incêndio - uma leitura das teses "sobre o 
conceito de história”. Tradução Wanda Caldeira Brant. São Paulo: Boitempo Editorial, 2005.

LUKACS, Georg. Ensaios sobre literatura. Rio de Janeiro: Civilização Brasileira, s/d. Teoria do Romance. São Paulo: Duas cidades; Ed. 34, 2000.

RICOEUR, Paul. A memória, a história, o esquecimento. Tradução: Alain François. Campinas, SP: Editora da UNICAMP, 2007

ROSENFELD, Anatol. Texto e contexto I. São Paulo: Perspectiva, 1996. . Texto e contexto II. São Paulo: Perspectiva, 1993.

SAID, Edward. Reflexões sobre o exílio. São Paulo: Companhia das Letras, 2003.

SEBALD. W. G. Austerlitz. São Paulo: Companhia das Letras, 2008. Os emigrantes. Rio de Janeiro: Record, 2002.

SELIGMANN-SILVA, Márcio. Local da diferença: ensaios sobre memória, arte, literatura e tradução. São Paulo, Editora 34, 2005.

. Testemunho e a política da memória: o tempo depois das catástrofes.

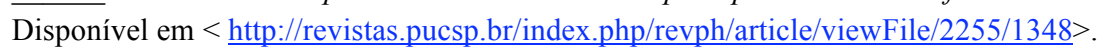
Acessado em: 05/11/2010.

. A catástrofe do cotidiano, a apocalíptica e a redentora sobre Walter Benjamin e a escritura da memória. In: DUARTE, Rodrigo; FIGUEIREDO, Virginia. Mimesis e expressão. Belo Horizonte: Ed. UFMG, 2001.

SONTAG, Susan. W. G. Sebald: el viajero y su lamento. Disponível em: <http://www.herreros.com.ar/melanco/sontag.htm>. Acessado em: 18/09/2009.

ZIZEK, Slavoj. Bem-vindo ao deserto do real!. São Paulo: Boitempo editorial, 2003.

\section{Notas}

${ }^{1}$ BENJAMIN. O narrador, p. 198.

${ }^{2}$ AGAMBEN. O que resta de Auschwitz, p.48

${ }^{3}$ SBALD. Os emigrantes, pp. 228-229

${ }^{4}$ ARENDT. Homens em tempos sombrios, p.176

${ }^{5}$ BENJAMIN apud ARENDT, Homens em tempos sombrios, p.176 
${ }_{7}^{6}$ JAMESON. Marxismo e forma, p. 69

7 BENJAMIN apud SELIGMANN-SILVA, Local da diferença, p. 367.

${ }^{8}$ SEBALD. Os emigrantes, p. 117

${ }^{9}$ BENJAMIN. Sobre o conceito de História, p.225

${ }^{10}$ LÖWY. Walter Benjamin - aviso de incêndio, p. 75

${ }^{11}$ BENJAMIN. Sobre o conceito de História, p. 224

${ }^{12}$ GAGNEBIN. Historia e narração em Walter Benjamin,p. 10

${ }^{13}$ BENJAMIN apud JAMESON. Marxismo e forma $\mathrm{p} .62$

${ }^{14}$ SEBALD. Os emigrantes, p. 119

${ }^{15}$ BENJAMIN. Sobre o conceito de História, p. 224

${ }^{16}$ SELIGMANN-SILVA. Local da diferença p. 373

17 SEBALD. Os emigrantes, p.28

${ }_{18}^{18}$ PROUST apud GAGNEBIN. Lembrar escrever esquecer, p. 153

${ }^{19}$ BENJAMIN. Paris do segundo império, p. 38

${ }^{20}$ BENJAMIN. Paris do segundo império, p. 39

${ }^{21}$ SEBALD. Os emigrantes, p. 222

${ }^{22}$ BENJAMIN. O narrador, p.207

${ }^{23}$ BENJAMIN. O narrador, p.207

${ }^{24}$ ADORNO apud SAID. Sobre causas perdidas,p.299 